\title{
Jiskry v Pionýrské organizaci ČSM (1959-1967)
}

\section{JIŘÍ KNAPÍK}

Knapík, Jiř́: Jiskry (Sparks) in the Pioneer Organisation of the Czechoslovak Youth Union (1959-1967)

This study describes the establishment of Jiskry (Sparks) as a part of the Pioneer Organisation of the Czechoslovak Youth Union in the late 1950s. The founding of the Jiskry clubs expanded and strengthened the system of extracurricular education for children too young for the Pioneer who until then had not been a part of the Czechoslovak Youth Union. In addition to the symbolism and specific activities of Jiskry, this study analyses specific problems, especially the lack of adult group leaders, which eventually led to the closing of this age group within the Pioneer Organisation of the Czechoslovak Youth Union at the end of 1967.

Key Words Children; Jiskry (Sparks); Extracurricular Education; Pioneer Movement; Propaganda

doi.org/10.15452/Historica.2021.12.0005

Contact Slezská univerzita vOpavě;jiri.knapik@fpf.slu.cz

\section{Úvodem*}

Komunistický režim v Československu od svého počátku usiloval o zásadní změnu přístupu k mladé generaci a soustředil se na vytvoření takového systému, který by zaručil vzdělávání a výchovu mladých lidí v socialistickém duchu. Zvláštní místo zaujímala kategorie školou povinných dětí. Jejich výchovu ve smyslu ideologických požadavků zajištovala nejen škola, ale také nově budovaná sít mimoškolních zařízení a spolu s nimi Pionýrská organizace ČSM (dále PO ČSM). PO ČSM vznikla v roce 1949 jako monopolní a tzv. jednotná dětská organizace určená pro chlapce a dívky od devíti let, která nahradila tradičního Junáka, organizaci na bázi pro režim zcela nepřijatelného skautingu. Zejména v prvním období existence komunistického režimu PO ČSM přejímala výchovnou praxi podle sovětského vzoru a soustředila se na růst členské základny. Úzké propojení pionýrského hnutí s prostředím školy a nezajímavá činnost poznamenaná různými „ideovými“ výstřelky se zejména od roku 1956 staly terčem kritiky. Tehdy v souvislosti s kritikou tzv. kultu osobnosti sledujeme postupnou změnu v př́stupu k pionýrskému hnutí, snahu o zatraktivnění pionýrské činnosti, větší respekt $\mathrm{k}$ potřebám různých věkových kategorií školáků a posléze i vnímavost k promýšlení pedagogických problémů s ohledem na domácí zkušenosti.

Podobné změny zaznamenala rovněž oblast mimoškolní výchovy. Během první dekády komunistického režimu postupně vznikala sít zařízení, která měla ovlivňovat i sféru volného času školáků. Klíčové postavení získaly zejména družiny mládeže pro děti zaměstnaných matek. Navzdory všem veřejným prohlášením však v tomto období vystupoval do popředí spíše sociální než výchovný význam družin. Až koncem 50. let sledujeme výrazné

Studie vznikla jako součást řešení grantového projektu GA ČR č. 19-10233S. 
změny v přistupu v mimoškolní výchově; politické orgány začaly klást důraz na zlepšení pedagogické práce s dětmi v družinách, na zvýšení kvalifikace vychovatelek, volalo se po zmírnění rozdílů v možnostech zájmové činnosti městských a venkovských dětí, začaly se vést odborné diskuse o poslání a metodách mimoškolní výchovy.

Závěr 50. a počátek 60 . let tedy představuje období nového akcentu na roli mimoškolní výchovy mladé generace. Šlo nepochybně o jeden z projevů př́íprav na vyhlášení socialistického charakteru státu, který se odrazil i v přijetí nového školského zákona v roce 1960. Hovořilo se o potřebě aktivizace Pionýrské organizace, obsáhnutí daleko většího objemu volného času dětí různými institucemi, začalo se diskutovat o zřizování tzv. škol s celodenní péčí. Problém volného času a institucionální výchovy dětí byl přitom společný pro řadu zemí tzv. sovětského bloku i západní Evropy. Dotýkal se nejen snah vyrovnat se s následky druhé světové války, ale postupně také potřeby řešit otázky spojené s modernizací společnosti; např. českoslovenští zástupci se v listopadu 1961 účastnili v Hamburku semináře UNESCO o problémech celodenní péče a jejího vztahu k rodinné výchově, na němž byli zastoupeni pedagogové ze Spolkové republiky Německo, Francie, Velké Británie a USA. ${ }^{1}$ Ve stejné době pořádala řadu konferencí o celodenní péči v socialistických zemích Německá demokratická republika, která v této oblasti získala velmi silnou pozici.

Právě v době zesíleného důrazu na roli mimoškolní výchovy se začala pozornost politických orgánů v Československu obracet $\mathrm{k}$ dětem ve věku od sedmi do devíti let. Nejmladší školáci totiž stáli doposud stranou pionýrského hnutí a kromě školy se výchovná a pedagogická péče o tyto děti omezovala na návštěvu školní družiny či zájmových kroužků; obojí přitom nemělo masový charakter. Je přitom překvapující, že v Československu soustavné mimoškolní aktivity zajištované pro tuto věkovou kategorii ustaly se zrušením Junáka, v němž tradičně působily oddíly vlčat a světlušek. Pionýrská hnutí, která vznikla v lidově demokratických zemích po roce 1945, totiž na děti do desátého roku věku pamatovala - a to po vzoru Sovětského svazu, kde se od roku 1924 přidružila k pionýrské organizaci tzv. oktabrjata (октябри́та). Např́ílad v Pionýrské organizaci E. Thälmanna (NDR) existovala od založení v roce 1948 kategorie Mladých pionýrů (Junge Pioniere) od první do čtvrté třídy, tedy dětí ve věku šest až deset let. ${ }^{2} \mathrm{~V}$ Bulharsku, po vzoru sovětských oktabrjat, byly do pionýrského hnutí začleněny děti do devíti let jako čavdarčeta (чавдарчета). ${ }^{3} \mathrm{~V}$ př́padě „sovětizovaných“ polských harcerů zůstala i po roce 1948 zachována formálně alespoň struktura dříve skautského hnutí, v níž měli místo nejmladší zuchy. Také jugoslávská pionýrská organizace, přestože se pokoušela od sovětského vzoru později odlišit, sdružovala všechny děti od šesti do čtrnácti let. ${ }^{4}$

Problematice Jisker v pionýrském hnutí v Československu nebyla dosud v odborné literatuře věnována adekvátní pozornost. Následující studie si proto klade za cíl přiblížit alespoň hlavní aspekty spjaté s existencí oddílů Jisker, a to na základě písemností Ústředního výboru ČSM, zejména předsednictva ÚV ČSM, Ústřední rady PO ČSM a pionýrského oddělení ústředního aparátu svazu mládeže. Zajímavé poznatky nabídl rovněž

\footnotetext{
1 -RO-: Seminář UNESCO o školách s celodenní péčí. Vychovávatel' 6, 1961/1962, č. 6, s. 192.

2 BOLZ, Alexander - LUND, Jörgpeter - POßNER, Wilfried: Die Pionierorganisation „Ernst Thälmann“ in der DDR. Berlin 2009, s. 12.

3 Какво се случи Преди '89-та? Исторически Сборник за Комунизма в България. Софиа, май 2017, s. 13; bg.wikipedia.org/wiki/Чавдарски_чети_в_Народна_република_Българ (cit. dne 12.2.2021).

4 ERDEI, Ildiko: „The Happy Child“ as an Icon of Socialist Transformation. Yuguslavia's Pioneer Organisation. In: LAMPE, John R. - MAZOWER, Mark (eds.): Ideologies and National Identities. New York 2004, s. 162.
} 
dobový pionýrský tisk, případně jiné tištěné prameny. Vzhledem k celkově málo probádané problematice předkládáme namísto kulturněhistorické sondy spíše materiálový text o okolnostech zakládání Jisker na konci 50. let, pozici věkové kategorie nejmladších školáků v Pionýrské organizaci ČSM, způsobu jejich organizování a formách aktivit Jisker. Celkový kontext vývoje Pionýrské organizace ČSM a pozadí výchovy mladé generace v socialistickém duchu, formované stanovisky politických orgánů Komunistické strany Československa, bylo přitom možné opřít o dosavadní literaturu, částečně reflektující také postavení Jisker. ${ }^{5}$

Optika pramenů centrálních institucí nám sice může zprostředkovat významné parametry vývoje Jisker v pionýrské organizaci, přesto je jejich pohled omezen na víceméně obecné rysy a př́ípadné výraznější odchylky z celkového rámce. Studii proto chápeme i jako podnět pro další výzkum zaměřený na odraz pokynů centrálních institucí v podmínkách okresních pionýrských rad OV ČSM či přímo na jednotlivých školách. Detailnější regionální sonda, která ovšem může opět odrážet některé specifické rysy zvolené lokality, by tak přispěla $\mathrm{k}$ našim znalostem o skutečné realizaci různých směrnic a praktických obtížích při jejich naplňování. Orálněhistorické bádání představuje další možný přístup k této problematice obohacující ji o byt' subjektivní, ale velmi osobní rozměr vnímání a prožívání. Naznačený směr dalšího výzkumu však jde již za rámec našeho záměru.

\section{Vznik a charakteristika Jisker}

O zřízení kategorie Jisker v rámci PO ČSM se na sklonku 50. let u nás neuvažovalo poprvé. V době likvidace Junáka a jeho transformace na Pionýrskou organizaci se sice krátce přistupovalo, po vzoru tzv. oktabrjat ze Sovětského svazu, ${ }^{6} \mathrm{k}$ vytváření oddílů i pro nejmenši školáky, nakonec k tomu ale nedošlo. Ještě v létě 1949 vedení svazu mládeže souhlasilo se zakládáním pokusných oddílů Jisker, jak se měly tyto organizační součásti PO ČSM nazývat, a skutečně na několika školách v Praze či Mostě opravdu vznikly, ${ }^{7}$ v následujícím roce se však o Jiskrách přestalo zcela hovořit. Doposud se nepodařilo nalézt dokument, $\mathrm{v}$ němž by stranické (či svazové) vedení rezignovalo na organizování dětí v Jiskrách. O důvodech, které k tomu (někdy na přelomu let 1949 a 1950) vedly, lze proto jen spekulovat. Jako velmi pravděpodobné vysvětlení se jeví to, že v době rychlého budování pionýrské organizace, které provázel hektický administrativní proces, komplikovaný i jistou rezistencí rodičů, byli všichni zainteresovaní (školy, svaz mládeže) zcela vytíženi. Vznik Jisker mohli vnímat jako relativně málo naléhavý politický úkol, byt tím Československo odlišili od ostatních monopolních organizací dětí a mládeže sovětského typu. Potíže spjaté se vznikem PO ČSM a zvláště nedostatek vedoucích pro pionýrské oddíly ovšem naznačovaly, že rozhodnutí nezakládat oddíly Jisker bylo racionální.

Možnost a potřeba práce s nejmladšími školáky však zůstala v rámci pionýrské organizace př́tomna, byt' pod povrchem hlavní agendy. Velmi dobře to dokládá organizace

\footnotetext{
Rámcově je vývoj Jisker načrtnut v knize KNAPÍK, Jiří - FRANC, Martin a kol.: Mezi pionýrským šátkem a mopedem: Děti, mládež a socialismus v českých zemích 1948-1970. Praha 2018; zde také další tituly odborné literatury vztahující se k problematice PO ČSM, školské politice a oblasti mimoškolní výchovy.

6 KELLY, Catriona: Children's World: Growing Up in Russia 1890-1991. New Haven - London 2007, s. 74.

7 HOFBAUER, Břetislav: Dětské hnutí v Československu v letech 1945-1949. Praha 1966, s. 159, 171; též Národní archiv (dále NA), fond 100/4 (M. Švermová), sv. 12, a. j. 72. Prozatímní řád Junáka z 3. 11. 1949 výslovně hovořil o tom, že Junák sdružuje děti od 6 do 15 let, přičemž děti od 6 do 9 let se na národních školách (1. až 3. ročník) sdružují v oddílech Jisker.
} 
dětského kolektivu při Dismanově rozhlasovém dramatickém souboru (dále DRDS) v první polovině 50. let. Tento tradiční umělecký soubor Československého rozhlasu stál jako celek na principech pionýrské organizace a nesl všechny známky vzorové pionýrské skupiny; uplatňovala se zde například dětská samospráva (skupinová rada, aktiv). V rámci DRDS působily celkem tři dětské kolektivy odlišené podle věku. Nejmladší věkovou kategorii zde reprezentovaly právě děti ve věku šest až devět let, které se označovaly jako Jiskry, konkrétně I. kolektiv Jisker DRDS Pavlíka Bř́nka. ${ }^{8}$ Zmíněný kolektiv tvořily čtyři oddíly Jisker po zhruba deseti dětech. Je zde zřejmé, že v tomto velmi dobře organizovaném a uměřeně početném dětském kolektivu nepředstavovala pionýrská práce s nejmladšími dětmi problém. Je přitom zajímavé, že označení Jiskry zůstalo v tomto př́ípadě zachováno. Jiskry v rámci DRDS kromě uměleckých aktivit byly současně vedeny k budoucímu vstupu do PO ČSM, tedy k jednomu ze základních cílů budoucích Jisker v celostátním měřítku.

V polovině 50. let se již setkáváme s ojedinělými hlasy, aby svaz mládeže a jeho pionýrská organizace začala soustavně pracovat také s dětmi předpionýrského věku. ${ }^{9}$ Dva roky poté se tato záležitost stala aktuální, nebot ji začalo zvažovat vedení ČSM; šlo o dobu, kdy akceleroval růst členské základy PO ČSM (připomeňme, že v roce 1955 byl pionýrem pouze každý druhý školák ve věku devět až patnáct let) a deklarování PO ČSM jako skutečně masové organizace se stalo politickou prioritou. Důležitým momentem se stalo VIII. plenární zasedání ÚV ČSM z konce prosince 1957. Tajemník ÚV ČSM Alois Poledňák na něm hovořil o dalším rozvoji pionýrské organizace a v této souvislosti výslovně uvedl, že je potřebné začít pracovat s dětmi nižšího věku od 1. tř́dy a vytvářet $\mathrm{z}$ nich jednoduché skupinky. ${ }^{10}$ Jeho slova se pak promítla do závěrečného usnesení, čím bylo naznačeno, že soustavná činnost s nejmladšími školáky formami pionýrské práce (hry, vycházky, předčítání) se stává oficiální směrnicí svazu pro jednotlivé pionýrské skupiny na školách. V této souvislosti nelze nepřipomenout ani možnou souvislost s děním v Sovětském svazu, kde VIII. plénum ÚV Komsomolu (1957) rovněž přistoupilo ke změnám v organizaci nejmenších školních dětí ve snaze zvýšit počet oktabrjat ve všech pionýrských skupinách. ${ }^{11}$

Vedení svazu mládeže se nicméně snažilo vytvořit zdání, že zájem o „pionýrskou práci“ mezi dětmi prvních až třetích tříd vzniká spontánně na řadě škol, zejména těch s aktivními pionýrskými skupinami. Z pramenů jsme informováni o řadě různých iniciativ nejstarších pionýrů, kteří se během roku 1958 pokoušeli pečovat o nejmladší školáky a vedoucích pionýrských skupin, kteří se cítili osloveni vcelku nenápadnou větou v obsáhlém usnesení VIII. pléna ÚV ČSM. Tyto skupiny dokonce adresovaly vedení svazu písemné výzvy, aby se systematická práce s nejmenšími školáky rozšířila do všech škol, a stala se tak prrípravou na jejich vstup do pionýrské organizace. Formulovala ji např́iklad předsedkyně skupinové rady a pionýři 20. jedenáctileté školy v Praze 16, na níž se také na

\footnotetext{
Plamen : Časopis Dismanova rozhlasového dramatického souboru 13, 1953/1954, č. 6-7, s. 11; tamtéž, č. 8-9 (př́loha Nástin vztahu DRDS k HRDM a nová organisace souboru DRDS od 1. IX. 1953), uloženo in: NA, fond ÚV ČSM, kart. 1413.

NA, fond ÚV ČSM, kart. 1420. Seminář vedoucích oddělení PO na KV ČSM (Černošice 1.-3. 4. 1955).

10 VIII. plenární zasedání Ústředního výboru ČSM 21.-22. prosince 1957. Praha 1957, s. 38; též NA, fond ÚV ČSM, kart. 112.

11 NA, fond ÚV ČSM, kart. 151. Předsednictvo ÚV ČSM 8. 1. 1959; srov. https://it.wikipedia.org/wiki/Oktjabrjata (cit. dne 4.9.2020).
} 
podzim 1958 uskutečnily improvizované sliby Jisker. ${ }^{12}$ Podobné výzvy od podzimu 1958 přinášel i pionýrský tisk, ${ }^{13}$ kde se tehdy začaly rovněž objevovat překlady sovětských statí práci s oktabrjaty. ${ }^{14}$

Jakousi odpovědí na toto „hnutí“ se stalo usnesení III. sjezdu ČSM z prosince 1958 o plošném zakládání oddílů Jisker. ${ }^{15}$ Komunistické Československo se tak vracelo k předúnorové tradici masové dětské organizace pro nejmenší školáky prvních až třetích tříd (od šesti do devíti let); v dané situaci však sledovalo posílení systematické a plošné mimoškolní výchovy této věkové kategorie. Co se týče názvu, politické vedení se přidrželo svým způsobem zavedeného názvu Jiskry z konce 40. let; stejně se např́lklad jmenoval žákovský čtenářský časopis vycházející v letech 1949-1950. ${ }^{16}$ Spojitost s pionýrskou symbolikou (třemi plameny v otevřené knize) je zjevná, spekulovat snad můžeme i o blízkosti s protežovanými husitskými tradicemi. ${ }^{17}$

Jiskry nevytvářely novou dětskou organizaci, staly se naopak integrální součástí Pionýrské organizace ČSM a byly chápány jako dobrovolné sdružení nejmladších školáků. Různé praktické, metodické a jiné záležitosti Jisker na celostátní úrovni připravovala (ve spolupráci s pionýrským oddělením ÚV ČSM) komise Jisker zř́izená při Ústřední radě PO ČSM, na jednotlivých školách práci Jisker řídilo vedení pionýrských skupin. Základním politickým a výchovným cílem Jisker se stala systematická a věku adekvátní příprava dětí na vstup do Pionýrské organizace. Podobně jako v případě pionýrů i zde oddíly Jisker (maximálně 18 dětí) sdružovaly děti jedné třídy. Jádro aktivit Jisker však spočívalo v tzv. hvězdičkách (pojmenování hvězdičky používaly mimochodem i dílčí skupinky u oktabrjat v Sovětském svazu) ${ }^{18}$ malých koedukovaných kolektivech pěti až sedmi dětí, ${ }^{19}$ které kromě společné třídy spojovaly i zájmy a také blízkost bydliště - kolektivy tedy měly vycházet $z$ existujících pout mezi dětmi. ${ }^{20}$ Kolektiv Jisker měl být také v principu jednoduchý - děti si ze svého středu nevolily žádné aktivisty.

Přestože Jiskry byly integrální součástí PO ČSM, lišily se od pionýrů nejen věkem, ale také specifickou symbolikou, která měla u dětí budit pocit sounáležitosti. ${ }^{21}$ Vedení svazu mládeže původně neuvažovalo o skládání zvláštního slibu, tento postoj nicméně počátkem ledna 1959 přehodnotilo. Krátký slib ve formě jednoduché „politické“ proklamace

\footnotetext{
12 NA, fond ÚV ČSM, kart. 151. Předsednictvo ÚV ČSM 8.1. a 12.3.1959. V dopise se uvádí, že práce s Jiskrami se na škole velmi osvědčila. Pionýři této školy docházeli za dětmi o přestávkách a vyprávěli jim pohádky, uspořádali výtvarnou soutěž, údajně seznamovali děti i s některými politickými událostmi, které již mohly pochopit. Dokonce prý sami vymysleli znění slibu: Jiskřičky jsme malé, máme však svůj cíl, budeme se dobře učit, aby byl vždy mír.

13 Hd: Jiskry a Jiskřičky. Pionýrské noviny, 23. 10. 1958, č. 43, s. 1.

14 PANOVA, Natalja A.: Staráme se o nejmenší. Vedoucí pionýrů 8, 1957-1958, č. 10, s. 5. K tomu též PANOVA, Natalja Sergejevna: Oktjabrjata: Dlja vožatych oktjabrjatskich grupp. Moskva 1961.

15 V předvečer sjezdu tento záměr schválilo IX. plenární zasedání ÚV ČSM 12. 12. 1958. NA, fond ÚV ČSM, kart. 113.

16 Zmiňme na tomto místě i kreslený seriál „Jiskrovci“ ilustrovaný Janem Fischerem, který vycházel na stránách časopisu Junáci vpřed! v letech 1949-1950. Viz http://www.daildeca.cz/fischerjunvpred.html (cit. dne 10.9. 2020).

17 Jiskrovci; Jan Jiskra z Brandýsa († asi 1469).

18 Srov. https://ru.wikipedia.org/wiki (Октябрята); cit. dne 12. 2. 2021; na zasedání předsednictva ÚV ČSM 8.1.1959 navrhl pojmenování „hvězdičky“ V. Vedra.

19 V roce 1958 se naopak setkáváme s chlapeckými a dívčími oddíly Jisker.

20 NA, fond ÚV ČSM, kart. 151. Předsednictvo ÚV ČSM 8. 1. 1959.

21 K tomu dále Tamtéž. Předsednictvo ÚV ČSM 8. 1. a 12. 3. 1959.
} 
se zavedl poměrně brzy. ${ }^{22}$ Kromě principu dobrovolnosti se přitom výrazně prosazovala zásada, že vstup dětí do Jisker neměly podmiňovat žádné jiné podmínky. Přesto se v pramenech setkáváme se zprávami, že do oddílů Jisker nebyli přijímáni žáci, kteří se nezúčastňovali přípravných schůzek nebo př́liš zlobili - měli ovšem možnost vstoupit do Jisker individuálně později. ${ }^{23}$

Při slibu děti dostávaly odznak Jisker; v prvních měsících se provizorně používala pionýry ručně vyrobená pěticípá hvězdička o průměru pět centimetrů, až v dubnu 1959 se pak zavedl první řádný (plátěný) odznak. Bílé košile a dívčí halenky společně s odznakem tvořily slavnostní kroj Jisker; odznak se nosil na levé straně hrudi. Odznak Jiskry současně nosily připnutý každodenně na školním oděvu, resp. občanském oděvu mimo školu. Později se vedle plátěných krojových odznaků zavedly kovové. ${ }^{24}$ Nejvyšším symbolem Jisker byl prapor pionýrské skupiny.

Odznak děti dostávaly (po vykonání slibu) při tzv. Svátku Jisker, tedy slavnostní ceremonii, která rovněž v průběhu roku 1959 získávala standardizovanou formu. Svátkům Jisker (a tím i založení oddílu) se vyhrazovalo především druhé pololetí prvního ročníku, aby děti měly nejprve možnost dostatečně se seznámit se školním prostředím. Předcházela mu navíc úvodní beseda s nejmladšími žáky, ${ }^{25}$ která zahajovala přípravné období ke vstupu do Jisker (analogicky ve třetím ročníku se Jiskry začaly připravovat na vstup do PO ČSM, k němuž se často vyhrazoval 24. duben, často také 25. únor, případně květnové svátky). Svátek Jisker, který završoval toto přípravné období, měl charakter slavnostní besídky připravované samotnými dětmi za pomoci (budoucího) vedoucího oddílu. $\mathrm{Na}$ akci byli zváni ředitel školy, pionýři patronátního pionýrského oddílu a samozřejmě rodiče dětí. ${ }^{26}$ Posléze Jiskry při této prŕležitosti získávaly členský průkaz.

Od počátku vedení svazu mládeže vytyčilo hlavní výchovné cíle Jisker, strukturované podle věku dětí. ${ }^{27}$ Trvalou zásadu samozřejmě představovala podpora života dětí v kolektivu a prohlubování vzájemných vazeb mezi dětmi ve školní třídě i mimo ni (tedy v rámci mimoškolních aktivit). Jiskry měly napomáhat vytváření pozitivního vztahu dětí ke škole a vzdělávání, upevňování vědomí povinnosti k zadaným úkolům ve škole i doma. Vedle toho se měl také rozvíjet správný vztah dětí ke světu okolo nich, domovu a obci, v níž žily.

22 Znění slibu: Jiskřičky jsme ještě malé, máme však svůj cíl. Budeme se dobře učit, aby byl vždy mír.

23 NA, fond ÚV ČSM, kart. 1436. Zpráva z průzkumu práce Jisker ve školních družinách okrese Trutnov (3.-9. 12. 1962).

24 Jiskry mají svůj odznak. Pionýrské noviny, 19. 3. 1959, č. 12, s. 4; Symboly Jisker. Tamtéž, 17. 11. 1960, č. 46, s. 4. Odznak tvořila rudá hvězda v otevřené knize (první povinnost Jiskry dobře se učit), kniha ležela v uzavřeném kruhu, z něhož šlehaly tři plamínky, které symbolizovaly tři generace (pionýry, svazáky a dospělé) pečující o Jiskry.

25 Metodický materiál stanovil, že schůzky se zúčastní i patronátní pionýrský oddíl, který jim představí budoucí vedoucí z řad nejlepších pionýrů. Ten den měly budoucí Jiskry poprvé vidět i prapor pionýrské skupiny a praporek patronátního oddílu. Je vhodné dát dětem perspektivu, že praporek pionýrského oddílu předají pionýri Jiskrám, když Jiskry založí svůj pionýrský oddíl. Tato tradice předání pionýrských symbolů má velký význam. Pak se Jiskry stanou opravdovou směnou pionýra. - NA, fond ÚV ČSM, kart. 151. Předsednictvo ÚV ČSM 12. 3. 1959.

26 Z návrhu metodického materiálu: Tento den se nesejdou pionýři s dětmi poprvé. Již před tím chodí pionýř $k$ dětem do tř́d, čtou jim pohádky, pomáhají děvčátkům šít šaty pro panenky, chlapcům zase poradí, jak dělat různéjednoduché výrobky z papíru, plsti, textilu, prírodního materiálu atd. Pionýři vysvětlí dětem zásady Jisker. Po zahájení školního roku se počítalo také s tím, že pionýři v prvních dnech pomohou prvňáčky vodit na obědy, ve větších městech pomohou s přecházením obtížných křižovatek na cestě do školy. NA, fond ÚV ČSM, kart. 151. Předsednictvo ÚV ČSM 12. 3. 1959. K tomu srov. H. L.: Slavnost Jisker. Vedoucí pionýrů 12, 1961, č. 1, s. 23; Svátek Jisker. Vedoucí pionýrů 14,1962 , č. 1 , s. 8 .

27 K tomu dále in: NA, fond ÚV ČSM, kart. 151. Předsednictvo ÚV ČSM 8. 1. a 12.3. 1959. 
Od druhého ročníku se přidávaly další znalosti a dovednosti osvětového (továrny v obci, pomník hrdiny druhé světové války) a částečně i branného charakteru, kam spadala například znalost některých zásad první pomoci, nejbližšího lékařského střediska, nádraží či požární služby. Ve třetím ročníku se nejstarší Jiskry pomalu adaptovaly na rámcový charakter budoucích pionýrských schůzek, včetně naplňování úvodních a jednoduchých požadavků výchovného systému Co má znát a umět pionýr (např. péče o čistotu a výzdobu školní třídy), plnění podmínek k získání stužky Mladý budovatel a veřejně prospěšných prací (např. jarní úklid, sběr odpadových surovin) - zpravidla ve druhém pololetí se pak oddíl Jisker přeměnil na oddíl pionýrský. ${ }^{28}$ Soubor základních pravidel posléze formulovaly Zásady Jisker. ${ }^{29}$

Již první ucelené pokyny z března 1959 zdůrazňovaly, že hlavní výchovnou metodou na schůzkách Jisker musí být hra a další formy činností odpovídající mentalitě a schopnostem dětí (vyprávění a hraní pohádek či krátkých příběhů, nácvik drobných písní, tanců, říkadel, soutěže). Děti měly například vhodně střídat zaměstnání, aby udržely dosud krátkodobou pozornost. Od druhého ročníku se již předpokládalo cílené pěstování veřejného mínění v kolektivu, tedy společná chvála správného jednání či odsuzování různých prohřešků. ${ }^{30}$ Výchova k mínění kolektivu měla přirozeně vyústit v první „politické“ rozhodování dětí: nejstarší Jiskry se totiž měly podílet na rozhodování, kdo se stane pionýrem. Učitel či vedoucí hvězdičky mohl dětem při jejich rozhodování napomáhat, nakonec však Jiskry o přihlášce každého spolužáka veřejně hlasovaly: Vedeme děti k tomu, aby otevřeně rekly svénázory každému, okom sejedná. Dospělínemohou svénázorydětem vnucovat. Dobře promyšlené a pripravené shromáždění poprvé ukáže dětem sílu kritiky a sebekritiky [...]. ${ }^{31}$

Formulování obecných výchovných postupů přitom zjevně odpovídalo speciálním pedagogickým dovednostem vyžadujícím pedagogické vzdělání a zkušenosti, což vzhledem $\mathrm{k}$ praxi budoucích oddílů Jisker - jak naznačíme v dalším textu - představovalo zásadní rozpor s představami o vedoucích Jisker. To se jen těžko dalo zakrýt či zmírnit publikováním „minima“ pedagogických zásad, jež zdůrazňovaly psychologická specifika dětí ve věku Jisker, ${ }^{32}$ nebo příkladů vzorné péče starších pionýrek o kolektivy Jisker; setkáváme se dokonce s formulacemi, že pionýrky o ně pečují s mateřskou láskou [...] Řídí se pritom i didaktickými zásadami. ${ }^{33}$

Vedoucím oddílu Jisker měl být dospělý, ideálně svazák. To bylo ovšem iluzorní vzhledem k tomu, že těch se nedostávalo ani v pionýrských oddílech. Už v roce 1960 se počet vedoucích oddílů propadl do citelného deficitu; v českých krajích se jich nedostávalo pro

\footnotetext{
28 Ke vzorové príípravě slavnosti vstupu do PO ČSM - Slib ve tř̌etí třídě. Vedoucí pionýrů 14, 1962, č. 1, s. 8; Z Jisker jsou pionýři. Pionýrské noviny, 20.1.1961, č. 3, s. 3.

29 Zásady Jisker: Jiskryjsou děti pilné, pracovité a ochotně pomáhají rodičům. Jiskry se pilně učí. Jiskry jsou družné, rády čtou, kreslí, zpívají, hrají si a vesele žijí. Jiskry jsou čestné a pravdomluvné děti. Jiskry se pripravují ke vstupu do Pionýrské organizace ČSM.

30 K tomu text předsedkyně skupinové rady školy v Říčanech nad Labem, pověřené vedením Jisker - KRUŽíKOVÁ, Hana: S Jiskrami do třetí třídy. Pionýrské noviny, 21. 4. 1960, č. 16, s. 4. U jiskry, která na schůzce vyrušovala, zvolila tento postup: Každého takového nezbedu přede všemi napomenu a děti samy pak určí, jak ho potrestat. Každý, kdo se musel zodpovídat celé hvězdičce, se zastyděl a choval líp.

31 VAŇKOVÁ, Soňa: Stanou se pionýry. Vedoucí pionýrů 15, 1963, č. 1, s. 9.

32 J. P.: Znáte je? Vedoucí pionýrů 14, 1962, č. 12, s. 7. Př́íspěvek v závěru odkazoval na speciální odbornou publikaci.

33 KRATOCHVÍL, Václav: Vyrůstají mezi přáteli. Tamtéž, č. 4, s. 8.
} 
3499 oddílů Jisker, zvláště svazáci o tuto roli nejevili v podstatě žádný zájem. ${ }^{34} \mathrm{~V}$ úvahu ještě připadali učitelé, zejména trrídní učitelé, případně vedoucí z řad rodičů (matek v domácnosti), deficit byl rovněž kamuflován tím, že Jiskry vedly vedoucí patronátního pionýrského oddílu. Každý vedoucí Jisker měl znát dostatečný počet pohybových her v místnosti a přírodě, písničky, pohádky, říkanky a tance určené pro mladší žáky, měl si umět poradit s výrobou drobných rukodělných dárků, které bylo možné upotřebit u prríležitosti Mezinárodního dne žen nebo jako dárky pro děti v mateřských školách na Mezinárodní den dětí. Vedoucí oddílu měl mít také přehled o učivu probíraném Jiskrami ve škole.

Vedle vedoucího oddílu pracovali s menšími kolektivy Jisker (tzv. hvězdičkami) vybraní starší pionýři - vzhledem k tomu, že řadě oddílů se ani nepodařilo získat řádného vedoucího oddílu, se tak žáci a mnohem častěji žákyně vyšších ročníků (sedmých až devátých tř́d) stávali hlavní, ne-li jedinou silou zajištující aktivity Jisker. Vedoucí hvězdiček Jisker se rekrutovali z patronátního pionýrského oddílu, pověřovaného skupinovou radou, resp. vedoucím pionýrské skupiny. ${ }^{35}$ Pokyny k zakládání Jisker upozorňovaly, že výběr vhodných pionýrů a pionýrek musí být velmi pečlivý, nebot nejmenší školáci rádi a rychle napodobují chování starších spolužáků, stávají se jejich vzory, velkou autoritou podobně jako učitel. ${ }^{36} \mathrm{Na}$ aktivity Jisker i vedoucích hvězdiček měl dohlížet rovněž třídní učitel (tedy třídy patronátního oddílu i třídy oddílu Jisker), doporučovalo se, aby se občas do schůzek Jisker zapojoval i celý patronátní pionýrský oddíl, a to např́íklad formou pionýrské estrády, sportovních her apod. Podobná podpora se očekávala také od rodičů a členů SRPŠ. Teoreticky byla rovněž vymezena role vedoucího pionýrské skupiny na škole; ten měl zodpovídat za sestavení plánu schůzek vedoucích Jisker, koordinaci tř́dních učitelů a vyhledávání vhodných vedoucích oddílů.

Úzká vazba Jisker a patronátních pionýrských oddílů se přitom záhy vydávala za jakousi pomocnou ruku samotné pionýrské organizace. Zakládala se na předpokladu, že práce starších pionýrů s mladšími spolužáky vytvoří pevnější vazby v kolektivu celé školy, podpoří samostatnost a iniciativu pionýrů. To ostatně stálo u samotného zdůvodnění potřeby založení Jisker v roce 1958 a zkušeností s vedením pokusných oddílů Jisker. V př́padě, že určitý pionýrský oddíl sám projevil zájem pracovat s konkrétním kolektivem Jisker, mělo se mu vyhovět a podpořit tak přirozené mezigenerační vazby dětí. ${ }^{37}$ Naděje se vkládaly i do toho, že ve vedoucích hvězdiček bude probuzen zájem o práci vedoucího pionýrů v budoucnu. ${ }^{38}$

První řádné oddíly Jisker vznikaly na školách už během ledna 1959. Celkem logicky se Jiskry ustavovaly nejprve na školách ve větších městech, ${ }^{39}$ nicméně vedení svazu mládeže od počátku usilovalo o to, aby nezaostávaly ani vesnické malotřídní školy; na nich

\footnotetext{
$34 \quad$ NA, fond ÚV ČSM, kart. 1430. V českých krajích bylo organizováno 12455 oddílů Jisker, z toho 8956 bez vedoucích.

35 NA, fond ÚV ČSM, kart. 151. Předsednictvo ÚV ČSM 8. 1. 1959; srov. např. MATIÁŠOVÁ, H.: Na cestu do nového roku. Pionýrské noviny, 1.1.1963, č. 1, s. 4.

36 NA, fond ÚV ČSM, kart. 151. Předsednictvo ÚV ČSM 12. 3. 1959; podobně TUHÁČEK, J.: Jiskry v družině mládeže. Vychovávatel' 5, 1960/1961, č. 2, s. 54-57.

37 K tomu srov. Z pošty z jednoho týdne. Pionýrské noviny, 15. 12. 1960, č. 50, s. 3; TENKRÁTOVÁ, L.: Od začátku společně. Vedoucí pionýrů 12, 1961, č. 4, s. 19; ČMOLÍK, Otto: Spolehliví přátelé. Vedoucí pionýrů 15, 1963, č. 1, s. 8 .

38 NA, fond ÚV ČSM, kart. 151. Předsednictvo ÚV ČSM 12.3.1959.

39 Viz např. informace dopisovatelů Pionýrských novin - První zprávy o Jiskrách. Pionýrské noviny, 8. 1. 1959, č. 1-2; př́loha Jiskra.
} 
se funkce vedoucího oddílu Jisker měli ujmout starší žáci, kteří z takové obce dojížděli do osmileté či devítileté školy ve městech. ${ }^{40}$ Celý proces samozřejmě provázela mohutná kampaň na školách a ve sdělovacích prostředcích, zvláště v dětských časopisech a pořadech v rozhlase a televizi. Rubriky určené přímo dětem-Jiskrám a samostatné přílohy vznikaly v Mateřídoušce a Ohníčku. Časopis Vedoucí pionýrů se zase orientoval na metodickou pomoc vedoucím oddílů (rubrika Vedoucím oddílů Jisker) a vedoucím hvězdiček (jim sloužila barevná příloha Jiskry) při zakládání oddílů a programu týdenních schůzek; vedoucí hvězdiček měli k dispozici celostránkovou rubriku Jiskra i v Pionýrských novinách. ${ }^{41}$ Průběžně byla publikována řada samostatných metodických materiálů. ${ }^{42}$ Televizní pořady určené Jiskrám zařadila Československá televize do programu od záŕi 1960; vysílaly se pravidelně jednou za měsíc.

„Jiskerská“ tematika se promítla zejména do měsíčníku Mateřídouška. Obsahově se měla stát zejména „časopisem Jisker“; v podnázvu se toto zaměření neprojevilo, nicméně komise Jisker při Ústřední radě PO ČSM uvažovala o tom, že znak Jisker se měl objevovat na (titulních?) stránkách časopisu. Různé příspěvky přitom začala provázet postavička Jiskřičky přibližující aktivity Jisker a mezi dětmi se údajně stala rychle populární. Redakce Mateř́doušky navíc zavedla stálou dvoustránku určenou pro vedoucí hvězdiček Jisker, která přinášela náměty na schůzky (hry, hádanky, scénky apod.). ${ }^{43}$ Rubrika se postupně stala klasickou volnočasovou př́lohou bez explicitního odkazu na Jiskry. ${ }^{44}$

Na konci roku 1959 již vedení svazu celostátně registrovalo 378 tisíc Jisker, v dalších letech se jejich počet pohyboval okolo půl milionu. V českých krajích, kde bylo zpočátku organizováno čtvrt milionu Jisker, jejich počet v roce 1964 přesáhl 300 tisíc. V roce 1966 nicméně počet Jisker výrazně poklesl, což částečně odráželo také demografický vývoj v této části republiky.

Tab. 1: Vývoj počtu Jisker v PO ČSM a organizovanost (v \%) v letech 1959-1966

\begin{tabular}{|c|c|c|c|c|}
\hline Rok & ČSSR & ČSSR (v \%) & České kraje & České kraje (v \%) \\
\hline 1959 & 378000 & - & - & - \\
\hline 1960 & $386758(\mathrm{k} 1.7)$. & 77,0 & $235767(\mathrm{k} 1.7)$. & 72,9 \\
\hline 1961 & 532000 & - & - & - \\
\hline 1962 & 474000 & - & - & - \\
\hline 1963 & $475848(\mathrm{k} 1.6)$. & 86,6 & $275911(\mathrm{k} 1.6)$. & 83,2 \\
\hline 1964 & 535824 & - & 320539 & - \\
\hline 1965 & 533586 & - & 310266 & - \\
\hline 1966 & 500724 & - & 230286 & - \\
\hline
\end{tabular}

\footnotetext{
$40 \quad$ NA, fond ÚV ČSM, kart. 151. Předsednictvo ÚV ČSM 12.3. 1959.

41 Např. Začněte s Jiskrami hned první den školy. Pionýrské noviny, 27. 6. 1959, č. 35, s. 3; Z deníku Jany Dvořákové. Tamtéž, 24. 9. 1959, č. 39, s. 3; Tamtéž, 24. 3. 1960, č. 12, s. 4.

42 Např. ČMOLÍK, Otto: ABC vedoucího hvězdičky Jisker. Praha 1962.

43 NA, fond ÚV ČSM, kart. 1430. Hodnocení časopisu Mateřídouška (1960).

44 SEKERÁKOVÁ, Anna: Př́běh Mateř́idoušky. Diplomová práce, Filozofická fakulta Univerzity Karlovy, Praha 2009, s. 36-37.
} 


\section{Jiskry a dětský kolektiv}

Prozatímní pokyny pro činnost oddílů Jisker vypracoval metodický kabinet Ústředního domu pionýrů a mládeže J. Fučíka společně s pionýrským oddělením ÚV ČSM koncem února 1959 a posléze je publikoval časopis Vedoucí pionýrů a další vhodná periodika. ${ }^{45}$ Během léta 1959 pak vznikly definitivní zásady práce s Jiskrami, které se průběžně v dalších letech zpřesňovaly podle aktuálních potřeb. ${ }^{46}$ Funkčnosti kolektivu Jisker měla napomoci zásada, aby nejmenší jednotka oddílu co nejvíce respektovala stávající přirozené dětské kolektivy. Hvězdičky Jisker se proto měly možnost formovat podle místa bydliště dětí; z podobného principu vycházelo rovněž doporučení, aby v družinách mládeže vznikaly tzv. družinové hvězdičky, které sdružovaly děti navštěvující společně jedno oddělení školní družiny. ${ }^{47}$

V zásadě lze rríci, že činnost Jisker se postupně adaptovala na hlavní formy pionýrské práce, a to tak, že některé aktivity mohly probíhat společně - v Přelouči např́íklad místní pionýři připravovali relace pro místní rozhlas nazvané Pionýrská jitřenka, přičemž pravidelnými hlasateli zde bývaly také Jiskry. Společně zde probíhal také pionýrský karneval. ${ }^{48}$ Jiskry druhé tř́ídy v Proboštově se zase pravidelně co dva týdny scházely se svým patronátním pionýrským oddílem. ${ }^{49}$ Úroveň schůzek Jisker se přitom okres od okresu i školu od školy velmi lišila. Odhalovaly to průběžné inspekce pionýrského oddělení PO ČSM. Výrazně pozitivně byly hodnoceny některé školy v okrese Trutnov, v nichž aktivity Jisker koordinovala okresní komise Jisker. Vedle pestré práce oddílů a hvězdiček se zde uskutečňovaly i pravidelné aktivy pionýrských pracovníků zodpovědných za činnost Jisker, dokonce se svolávaly konference vedoucích hvězdiček, na nichž mladí pionýři prezentovali své zkušenosti a dostávali instrukce $\mathrm{k}$ další činnosti. ${ }^{50}$

Počátkem 60. let bylo zvláště vyzvedáváno sepětí pionýrského kolektivu a Jisker a tím posilování zásad komunistické výchovy mezi nejmladšími žáky. Patronátní pionýrské oddíly měly na mladší spolužáky všemožně působit jako vzor. Nezištná pomoc pionýrů Jiskrám s přípravou na vyučování a plněním jiných školních povinností se označovala za projev tzv. timurovského hnutí, ${ }^{51}$ Jiskry zase motivovány tímto príkladem měly samy vykonávat tzv. timurovské činy a drobné úkoly. Ty potom nalézaly patřičný ohlas v tisku. ${ }^{52}$ Vedle těchto individuálních př́kladných činů zde samozřejmě existovaly příkladné aktivity, které plnily Jiskry (po vzoru pionýrů) v kolektivu - zejména šlo o přiměřeně náročné

45 NA, fond ÚV ČSM, kart. 151. Předsednictvo ÚV ČSM 8. 1. 1959. Tyto pokyny byly spíše praktického rázu, rozhodně neměly působit jako stanovy nové organizace; viz KRUPAUER, Josef: Zakládáme Jiskry. Vychovatel 3, 1959, č. 4, s. 117-118.

46 Srov. Pokyny pro činnost oddílů Jisker pro školní rok 1960/1961. Věstník ministerstva školství a kultury 16, 1960, s. 292; -hm-: Zásady jisker. Pionýrské noviny, 12.11. 1963, č. 11, s. 4; Jiskry v novém školním roce. Vedoucí pionýrů 17,1965 , č. 9 , s. 12.

47 NA, fond ÚV ČSM, kart. 1436; též Vedoucím oddílů Jisker. Vedoucí pionýrů 14, 1962, č. 9, s. 7.

48 KRATOCHVÍL, Václav: Vyrůstají mezi přáteli. Vedoucí pionýrů 14, 1962, č. 4, s. 8.

49 VELINSKÁ, Maruška: Pionýři a my, Jiskry. Pionýrské noviny, 2. 6. 1961, č. 22, s. 4.

50 NA, fond ÚV ČSM, kart. 1436. Zpráva o okresní konferenci vedoucích hvězdiček Jisker v Trutnově 2. 3. 1962. Z prezentace pionýrů mj. vyplynulo, že na schůzkách Jisker upřednostňovali předčítání, kreslení a výrobu dárků před pohybovými hrami či turistikou.

51 Tzv. timurovské hnutí se vztahovalo ke známému dílu A. Gajdara Timur a jeho parta (1940). Pionýři po vzoru Timura měli (často tajně, a tedy nezištně) pomáhat malým dětem, slabým jedincům či starým lidem. Timurovský čin byl proto chápán jako pionýrský, veřejně prospěšný dobrý skutek.

52 KRHOUNKOVÁ, Hana: Jiskry - timurovci. Pionýrské noviny, 13. 1. 1961, č. 2, s. 3. Informace o čtyřech chlapcích-Jiskrách, kteři složili sedmdesátileté stařence dvě tuny uhlí. 
veřejně prospěšné práce (úprava okolí školy, obce, boj proti plevelům, sběr odpadových surovin apod.). Také Jiskry se proto mohly zúčastnit celostátní soutěže o stužku Mladý budovatel, a to s upravenými podmínkami ÚV ČSM (odpracování tří brigádnických hodin, získání pěti kilogramů odpadového papíru, deseti dekagramů léčivek; také tyto úkoly měly být Jiskrami plněny zásadně v kolektivu. ${ }^{53}$ Kolektivní ráz mělo přirozeně také hnutí ze tř́dy do třídy celý oddíl společně zaměřené na udržení dobrého prospěchu a snížení propadovosti žáků; i toto „hnutí“ měli propagovat pionýři mezi Jiskrami. ${ }^{54}$

Jak jsme výše zmínili, těžiště aktivit Jisker mělo spočívat v tzv. hvězdičkách. Jejich vedení dostávali na starost pionýři nejvyšších ročníků; nejčastěji se jednalo o děvčata osmých a devátých tř́íd. ${ }^{55}$ Vzhledem k nedostatku řádných vedoucích oddílů nebylo ještě v roce 1959 výjimkou, že starší pionýrky (sedmých tříd) vedly dokonce celý oddíl Jisker. ${ }^{56}$ Už počátkem 60. let se setkáváme s kritikou vedení svazu mládeže, že s Jiskrami fakticky pracují pouze starší pionýři. Možnosti, jak tuto situaci změnit, byly velmi omezené, fakticky nulové.

S tím úzce souvisí ožehavý problém odpovědnosti nejstarších žáků za bezpečnost dětí na schůzkách Jisker, zvláště uvážíme-li, že kontakt pionýrů a Jisker měl být relativně častý. ${ }^{57}$ Teoreticky mohl tento problém brzdit růst organizovanosti Jisker. Např́klad žačka z Koštan u Teplic, která vedla Jiskry 1. třídy, se v tisku svěřila, že rodiče zakázali dětem chodit na schůzky, nebot' měli obavy o jejich bezpečnost. ${ }^{58} \mathrm{~V}$ takových př́ipadech se doporučovalo, aby pionýři zvali rodiče na schůzky, nechali si od nich poradit a nenásilně zapojili matky Jisker do vedení schůzek. ${ }^{59}$ Praxe ovšem ukázala, že ani to nevedlo k řešení absence plnohodnotného pedagogického dohledu.

Jiný způsob řešení problému představovala systematičtější příprava vedoucích hvězdiček, zejména těch, kteří se věnovali Jiskrám 1. tříd. Interní materiály pionýrského oddělení ÚV ČSM poněkud eufemisticky a s typickým administrativním tónem přiznávaly, že vedoucí hvězdiček nejsou na náročnou práci s dětmi připraveni, a to z hlediska obsahu i metodiky. ${ }^{60}$ Vedení Ústřední rady PO ČSM schválilo už v prosinci 1963 osnovu systému př́pravy vedoucích hvězdiček Jisker v první tř́dě, která vznikala experimentálně během šesti měsíců ve vybraných pěti pionýrských skupinách Východočeského a Středočeského kraje. Na základě získaných zkušeností pak komise Jisker zpracovala metodiku školení hvězdiček Jisker, která měla přispět ke zlepšení práce s nejmenšími Jiskrami. Materiál

\footnotetext{
53 Srov. Také Jiskry soutěží. Pionýrské noviny, 6. 10. 1960, č. 40, s. 4.

54 NA, fond ÚV ČSM, kart. 1430. Zásady pro činnost oddílů Jisker pro školní rok 1960/1961.

55 V roce 1966 bylo v českých krajích 16264 vedoucích oddílů Jisker, z toho jen 1078 chlapců. NA, fond ÚV ČSM, kart. 168. Dále též RAMPASOVÁ, Jana: Děvčata a Jiskry. ABC mladých techniků a prírodovědců 3, 1959, č. 2, s. 20. Časopis $A B C$ také přinášel v rámci dívčí rubriky náměty pro činnost Jisker. VEITOVÁ, Ivona: Odpoledne s Jiskrami. Tamtéž 5, 1961, č. 7, s. 20.

56 Napsali nám. Pionýrské noviny, 19.3.1959, č. 12, s. 4. V tomto konkrétním případě vedly oddíly Jisker 1 . tříd žákyně 7. tříd osmileté školy v Chocni.

57 Žačka 9. třídy popsala případ, kdy chlapec vyběhl na most k přijíždějícímu vlaku a nebezpečně se nakláněl přes zábradlí, přičemž jej impulzivně následovala celá skupina dětí. ŠVERMOVÁ, Stáňa: Co dělám nejraději. Pionýrské noviny, 17.10.1960, č. 42, s. 4.

58 Jiné důvody v tomto případě nebyly uvedeny, nelze samozřejmě vyloučit ani odmítání Jisker ze stejných důvodů jako v př́ípadě vstupu dítěte do PO ČSM.

59 Bětka si neví rady. Pionýrské noviny, 21. 1. 1960, č. 3, s. 4; Radíme Bětce. Pionýrské noviny, 18. 2. 1960, č. 7, s. 4.

60 NA, fond ÚV ČSM, kart. 1441. Jednání vedení ÚR PO ČSM 28. 2. 1964.
} 
však současně odhalil, že kromě vedoucích oddílů se už nedostávalo ani vhodných vedoucích hvězdiček, nebot' vedení svazu muselo začít počítat pro funkci vedoucích hvězdiček i s žáky šestých tříd! Systém školení určený pionýrům z šestých tříd před nástupem do funkce byl rozpracován do 40 hodin a měl se zavádět od školního roku 1964/1965, vždy od ledna. Základní materiály byly publikovány průběžně v časopise Vedoucí pionýrů a také v samostatné brožuře. ${ }^{61}$ Budoucí vedoucí měli projít klasickým teoretickým školením, praktickými kurzy pionýrských kolektivů v př́rodě o sobotách a nedělích, v plánu byla také táborová škola, která měla průběžně upevňovat získané dovednosti.

Zajímavou otázku představovala práce s Jiskrami v družinách mládeže. Zařízení mimoškolní výchovy se totiž od počátku zaměřovala zejména na péči o žáky prvního stupně - ti také představovali největší podíl školáků navštěvujících družinu. Etapa zakládání oddílů Jisker tedy souvisela spíše s potřebou podobné adaptace vychovatelů jako v př́padě pionýrů - u nich se aktivity (mimo přípravu na vyučování) od konce 50 . let soustředily na potřeby výchovného systému Co má znát a umět pionýr. Různé hry, ruční práce a další podobné činnosti v družinách tvořily jádro aktivit vychovatelek s nejmladšími žáky už dřive. $\mathrm{V}$ tomto smyslu Jiskry vytvářely pouze nový rámec a formu, více směrovanou na budoucí vstup dětí do PO ČSM. ${ }^{62}$ Zmiňme zde ještě, že už v předvečer zakládání oddílů Jisker vznikaly mimoškolní kolektivy nejmladších školáků; např́iklad v okrese Jičín se při školách na přelomu let 1958/1959 zakládala tzv. Klubíčka. Jednou měsíčně se zde při hrách setkávaly děti, které projevily zájem o vstup do Jisker. Školy k založení oddílů přistupovaly až po proškolení vedoucích. ${ }^{63}$

Přesto družiny mládeže měly plnit jednu zajímavou funkci právě s ohledem na organizaci dětského kolektivu. Souviselo to s přirozeným a neorganizovaným dětským kolektivem mimo dohled institucí. Takovým modelovým kolektivem mohl být hlouček prvňáků pod vedením staršího kamaráda“, který „staví na potoce hráz, hraje si na školu, dělá tunely v písku nebo prolézá tajemná zákoutí dvora, domu, parku či staveniště. I na takový věkově smíšený kolektiv bylo možné prostřednictvím starších dětí dohlédnout, aby $i$ bez naší př́tomnosti tato partička nevyváděla nic špatného a neškodila mravně sobě a hmotně svému okolí. Jak dovozoval pracovník mariánskolázeňského DPM J. Tuháček: lze do nich jako „náčelníky“ dosadit nejlepší proškolené pionýry, které už pod svým vlivem máme. ${ }^{64}$ Právě družiny mládeže mohly podle Tuháčka sloužit k upevnění vztahů pionýrů a Jisker a překlenout rozdíl mezi pobytem dětí v družině a mimo ni. Nešlo pouze o to, že práce voddíle Jisker nám pomůže vychovávat z pionýrů dobré oddílové vedoucí, kterých máme stále nedostatek, a preklenout věkovou propast mezi dětmi pionýrského věku a členy svazu mládeže. Poukázal na problém řady vychovatelek, zda mohou mladší žáky předčasně pustit z družiny s pionýry šestých až osmých tříd na schůzku Jisker. V Mariánských Lázních jej vyřešili tak, že pionýr-vedoucí hvězdičky se měl domluvit s vychovatelkou, kam s Jiskrami půjdou a ona se $\mathrm{k}$ nim později přidala s ostatními dětmi - vedoucímu Jisker mohla poradit a on měl zase možnost pozorovat, jak to s dětmi dělá ona. Zásadní význam takové praxe však spočíval ve zvýšení pravděpodobnosti, že s takovým pionýrem se tyto děti rády sejdou i ve volném čase, v sobotu, neděli, kdy je družina mládeže zavřená. Rodiče budou

\footnotetext{
${ }^{61}$ K tomu LOKAJÍČKOVÁ, Jiřina: Jiskry v první tř́dě. Praha 1964.

62 K tomu více metodický sborník ČMOLÍK, Otto (ed.): Než si šátek uvážeš : Některé náměty k práci oddílů Jisker. Praha 1959.
}

63 (P): Na cestě k Jiskrám... Pionýrské noviny, 29. 1. 1959, č. 5, s. 3.

64 TUHÁČEK, J.: Jiskry v družině mládeže. Vychovávatel' 5, 1960/1961, č. 2, s. 54-57. 
klidni, když budou vědět, že na děti dohlédne tentýž pionýr, která na ně dohliží i v družině mládeže. ${ }^{65}$

Podobně jako v případě družin mládeže se vyvíjelo řešení práce s Jiskrami během letních prázdnin. Přestože se pravidelný kontakt vedoucích hvězdiček s Jiskrami přerušil, byli vedoucí nabádáni k tomu, aby se ujímali Jisker například na pionýrských táborech a pokračovali v práci s jiným dětským (jiskerským) kolektivem. ${ }^{66}$ Práce s Jiskrami se počátkem 60 . let tudíž pokládala za samozřejmou součást aktivit PO ČSM na letních táborech; metodické materiály (vedle výzev vedoucím hvězdiček pokračovat v práci s jiskrami i v létě) doporučovaly, aby se do programu zařazovaly tzv. Dny Jisker, chápané jako slavnostní vyhodnocení táborových aktivit Jisker. ${ }^{67}$ Kromě toho experimentálně vznikaly i letní tábory určené pouze dětem jiskerského věku. Takový (dvoutýdenní) tábor organizoval DPM v Praze-Karlíně pro čtyři desítky Jisker místních škol; první rok se uskutečnil v prostorách partnerské školy v Hradci Králové, následující rok se tábor pořádal již jako stanový a jeho součástí se stalo třídenní putování v Orlických horách. Tábor současně sloužil jako školicí středisko pro hvězdičky Jisker, které se na organizaci a práci s Jiskrami podílely. Chtěli jsme si v praxi vyzkoušet, co všechno se dá s malými Jiskrami udělat, na co stačí jejich síly a schopnosti, jak se osvědčí v každodenním táborovém životě - bez maminek a bez tatínků, jen za pomoci vedoucích a svých starších přátel, pionýrů. Chtěli jsme také vyzkoušet, jak se na táboře osvědčí a uplatní tito pionýři - vedoucí hvězdiček, a připravit je i na další práci s Jiskrami během celého roku. ${ }^{68}$

\section{Jiskry, nebo mladší pionýŕi?}

Už v polovině 60. let společně s postupující liberalizací se začalo veřejně přiznávat, že se Pionýrská organizace ČSM nachází v krizi a spolu s ní také Jiskry. Dosavadní nadšené komentáře vystř́idala kritika a pochyby. Časopis Vedoucí pionýrů tehdy přinesl příznačně kritický příspěvek, kterým reagoval na hromádku dopisů vedoucích hvězdiček (suplujících často chybějící vedoucí oddílů Jisker), dopisů plných nevyslovených výčitek. Pionýři se v nich svěřovali, že jim nikdo s vedením Jisker nepomáhá, sami svěřené děti těžko zvládají a těžko mohou větší kolektiv Jisker zaujmout nějakou společnou činností. Redakce tyto dopisy uvedla slovy: Žaluji ve své bezradnosti vás, dospělé, vás, kteří jste precenili mou ochotu a chut' být s menšími dětmi - a svěrili mi se vším všudy jejich výchovu. Ještě mi není patnáct a mám si vědět rady s tolika dětmi v každé situaci. Přečetla jsem si, že vedoucím oddílu má být někdo z dospělých lidí [...] a my, pionýři a nejmladší svazáci, máme vést pětičlenné nebo nejvýš sedmičlenné skupinky Jisker. Tak by se mi to líbilo [...] ${ }^{69} \mathrm{Z}$ nedostatku kvalitních vedoucích s odpovídajícím vzděláním a zkušenostmi přitom redakce vyvozovala další závažné závěry: Co mohou děti očekávat od toho, že se stanou pionýry, když už

\footnotetext{
65 Tamtéž. K pomoci vychovatelek pionýrům (vedoucím hvězdiček) s programem schůzek Jisker - STARÁ, H.: Systém „Co má znát a umět pionýr“ ve výchovných zařízeních. Vychovávatel'6, 1961/1962, č. 8, s. 231-237.

66 I Jiskry budou mít prázdniny. Pionýrské noviny, 16. 6. 1960, č. 25, s. 4.

67 Den Jisker na táboře. Vedoucí pionýrů 12, 1961, č. 6, s. 8; JANČíKOVÁ, Z.: Jiskry jedou s námi. Vedoucí pionýrů 15, 1963, č. 6, s. 20-21.

68 NOVÁKOVÁ, Eliška: Tábor Jisker. Vedoucí pionýrů 16, 1964, č. 3, s. 20.

69 PIŠVEJCOVÁ, Eva: Já, vedoucí hvězdičky Jisker, žaluji... Vedoucí pionýrů 17, 1965, č. 2, s. 15.
} 
jako Jiskry zažily zklamání? S jakým nadšením se z vedoucích hvězdiček Jisker mohou stát vedoucí pionýrü, nenajdou-li nikde pochopení a pomoc? ${ }^{70}$

Skutečnost, že se kategorie Jisker v rámci PO ČSM nachází na rozcestí, vedla na jaře 1966 k př́pravě celostátního dvoudenního semináře pionýrských a pedagogických pracovníků s cílem analyzovat dosavadní zkušenosti s oddíly Jisker, pojmenovat hlavní potíže s vedením kolektivů Jisker a doporučit řešení obtíží. Významný prostor byl věnován rovněž problematice přijetí dětí do Jisker, přechodu do Pionýrské organizace a také symbolice Jisker. Seminář se sešel počátkem prosince téhož roku. ${ }^{71}$ Účastníci měli možnost se dopředu seznámit s obsáhlým materiálem vypracovaným pracovnicí brněnského Krajského pedagogického ústavu Jaroslavou Vališovou, na který př́mo navazoval na semináři prezentovaný referát Tatiany Miškuvové, pracovnice bratislavského Domu pionýrů a mládeže a členky komise Jisker Ústřední rady PO ČSM.

Expertíza Jaroslavy Vališové reflektovala situaci Jisker otevřeně a kriticky. Přiznala, že po počátečním nadšení a zájmu starších školáků věnovat se zakládání oddílů Jisker se rychle objevily základní nedostatky, jejichž společným jmenovatelem se stalo nedostatečné pedagogické zázemí pro aktivity Jisker. Upozornila na to, že v současnosti v oddílech Jisker představují nejpočetnější kategorii vedoucích samotní pionýři (chlapci a dívky ve věku dvanáct až patnáct let), přičemž šlo o nejmladší vedoucí v pionýrské organizaci vůbec, kteří byli s Jiskrami často v denním kontaktu. V současné praxi jsou navíc také většinou jedinými vedoucími Jisker vůbec. Bylo zdůrazněno, že výchovné cíle při nejlepší vůli nemohou splnit bez soustavného usměrňování a vedení dospělých vedoucích. ${ }^{72}$ Situaci tudíž nebylo možné řešit apely na kvalitu vedoucího hvězdiček, ale tím, že práci s Jiskrami zásadně posílí dospělí výchovní pracovníci (nebo alespoň členové ČSM), což ovšem vedlo k těžko řešitelným problémům, nebot' právě takových se nedostávalo. Pokud by se například kategoricky trvalo na tom, aby oddíly vedli dospělí, mnoho oddílů by zaniklo. Východisko nenabízely ani matky nejmladších školáků, protože postrádaly pedagogické vzdělání.

Seminář se kromě problému vedoucích oddílů zabýval úpravou symboliky Jisker (bylo např. navrhováno doplnit kroj šátkem), rozpracováním procedury individuálního vstupu dětí do Jisker a přijetí do Pionýrské organizace. Vznesl navíc důležité doporučení posunout věkovou hranici členství v Jiskrách z šesti na sedm let (tedy od druhé třídy). Požadavek, aby se Jiskrám v oddílech věnovali členové ČSM, dospělí a (v nejlepším přípravě) kvalifikovaní pracovníci sice nebyl nijak nový, ale v situaci na přelomu let 1966/1967 přivedl Jiskry do slepé uličky. Vzhledem k tomu, že se v předvečer sjezdu ČSM intenzivně diskutovala reforma Pionýrské organizace, v jejímž rámci bylo možné zakládat pionýrské skupiny i mimo školy, zužoval se tím ještě více okruh možných dospělých vedoucích oddílů. Společně s návrhem na úpravu věku Jisker tak vykrystalizovalo úplně jiné řešení úvah o práci s Jiskrami, než jaké celostátní seminář z prosince 1966 zamýšlel - př́íprava na nenápadné zrušení Jisker. V podstatě se jednalo o racionální krok chápaný jako odstranění jedné z dílčích překážek reformy PO ČSM. ${ }^{73}$

\footnotetext{
$70 \quad$ Tamtéž. $Z$ dopisů došlých redakci: [...] v naší práci nám nikdo nepomáhá. Soudružka trídní učitelka se nás sice zeptá, co s dětmi budeme dělat, že se přijde podívat, Opravdu přjide. Ale co je nám to platné, když se prijje jenom podívat [...]; [...] oni sami nevědí, co by je bavilo. Jedni chtějí kreslit, druzí cvičit atd. Kolikrát jsme si již rozvrhli přesný program. Ani to se jim nelíbí. Poradte nám, co máme dělat. Čekáme na vaši odpověd'jako na záchranu.

71 NA, fond ÚV ČSM, kart. 1449. Celostátní seminář „Činnost oddílů Jisker“ 1. a 2. 12. 1966.

72 Tamtéž.

73 Podrobněji KNAPÍK, J. - FRANC, M. a kol.: Mezi pionýrským šátkem, s. 359-360.
} 
Během jara 1967 tak zrálo přiznání, že vznik Jisker přinesl Pionýrské organizaci spíše potíže a prohluboval její komplikovanou situaci. Přitom ještě v lednu 1967 návrh nových stanov ČSM s Jiskrami jako přidruženou kategorií dětí počítal, o Jiskrách se v předsjezdových materiálech z února 1967 nadále psalo jako o důležité součásti PO ČSM. ${ }^{74}$ Zásadní rozhodnutí padlo někdy v květnu 1967, kdy při finalizaci návrhu nových stanov Jiskry z jejich textu zmizely. ${ }^{75}$ Červnový V. sjezd Československého svazu mládeže pak odsouhlasil snížení věku člena Pionýrské organizace z devíti na osm let. ${ }^{76}$ Je zajímavé, že zrušení Jisker nebylo nikde výslovně uvedeno, zato se od podzimu 1967 začalo fakticky uskutečňovat. Předsednictvo ÚV ČSM v září 1967 schválilo rozhodnutí Ústřední rady PO ČSM neprovádět od nového školního roku 1967/1968 v prvních tříách „Svátky Jisker“ s tím, že od září 1968 se přistoupí k přijímání nejmladších členů PO ČSM už podle nových stanov, tedy osmiletých dětí. Mezitím byla pověřena pracovní skupina ÚR PO ČSM, aby připravila návrhy na formy práce s mladšími pionýry (do jedenácti let), které by kombinovaly výchovný systém Plamenů s metodikou práce se staršími Jiskrami. ${ }^{77}$ Starší Jiskry přitom samozřejmě mohly vstoupit do PO ČSM; pokud dítě o přijetí požádalo, muselo se prokázat základními znalostmi o Pionýrské organizaci a vykonat veřejně prospěšný čin. ${ }^{78}$

\section{Závěrem}

Začlenění systematické práce s nejmladší věkovou kategorií školou povinných dětí do činnosti Československého svazu mládeže lze hodnotit spíše rozporuplně. Zdá se, že na přelomu 50. a 60. let, v době odvážných až fantaskních chruščovovských vizí, jimiž se politické orgány v Československu inspirovaly, měly Jiskry napomoci ještě více rozšiřit členskou základnu Pionýrské organizace ČSM, a prezentovat ji tak jako skutečně masovou dětskou organizaci českých a slovenských dětí. Kromě toho měly Jiskry posílit systém získávání nejmladších pionýrů, nebot' mezi základní politická zdůvodnění jejich existence náležela příprava dětí na vstup do PO ČSM. Tento formální přístup však ve skutečnosti ještě více prohloubil reálné potíže, jimž PO ČSM v té době čelila. V př́ípadě Jisker se sice podařilo vytvořit rejstřík aktivit, jenž doplňoval dosavadní možnosti sítě mimoškolních zařízení pro děti ve věku šest až devět let, z dlouhodobého hlediska se však nepodařilo Jiskrám zajistit adekvátní pedagogické zázemí z řad dospělých vedoucích, jichž se nedostávalo ani řádným pionýrským oddílům. Ve skutečnosti tak těžiště práce s nejmenšími dětmi spočívalo na tzv. vedoucích hvězdiček, tedy nejčastěji na žačkách sedmých až devátých tříd, které při nejlepší vůli nemohly zastat pedagogicky hodnotnou a výchově odpovídající péči. Uvedené těžkosti přivedly (společně s přípravou reformy Pionýrské organizace ČSM) v roce 1967 politické orgány k rozhodnutí Jiskry postupně rozpustit.

Obnovený zájem o systematickou práci s nejmladšími školáky přineslo paradoxně období Pražského jara. Reformovaný Pionýr tehdy přehodnotil zhruba půl roku starý postoj k Jiskrám a začal je opět vnímat jako zajímavou věkovou kategorii školáků, díky níž bude možné postupně konsolidovat vlastní členskou základnu a která současně přinese jakousi „konkurenční výhodu“ vůči obnovenému Junáku. Koncem roku 1968 Pionýr

74 NA, fond ÚV ČSM, kart. 168. Předsednictvo ÚV ČSM 13. 1. a 2. 3. 1967.

75 Tamtéž, kart. 169. Předsednictvo ÚV ČSM 11. 5. 1967.

76 Stanovy ČSM. In: V. sjezd Československého svazu mládeže. Praha 1967, s. 110.

77 NA, fond ÚV ČSM, kart. 170. Předsednictvo ÚV ČSM 28. 9.1967.

78 Tamtéž, kart. 1454. Návrh pokynů ÚR PO ČSM k přechodu Jisker do PO ČSM (19. 1. 1968). 
sdružoval více než 32 tisíc Jisker. ${ }^{79}$ Jen dva roky poté již vývoj opět směřoval k likvidaci samostatných dětských organizací a k opětovnému vytvoření monopolního Svazu socialistické mládeže a jeho Pionýrské organizace v listopadu 1970. V rámci PO SSM tvořily Jiskry opět nedílnou součást členské základny, jejich výchovný systém v době tzv. normalizace a případné odchylky od praxe z konce 50. a 60. let však již leží mimo rámec naší studie. $^{80}$

\section{Bibliografie}

\section{Archivní prameny}

Národní archiv, fond Marie Švermová

Národní archiv, fond Ústřední výbor Československého svazu mládeže

\section{Tištěné prameny}

ABC mladých techniků a prírodovědců 1959, 1961.

ČMOLíK, Otto (ed.): Než si šátek uvážeš. Některé náměty k práci oddílu Jisker. Praha 1959.

ČMOLÍK, Otto: ABC vedoucího hvězdičky Jisker. Praha 1962.

HOFBAUER, Břetislav: Dětské hnutí v Československu v letech 1945-1949. Praha 1966.

LOKAJÍČKOVÁ, Jiřina: Jiskry v první třídě. Praha 1964.

PANOVA, Natalja Sergejevna: Oktjabrjata: Dlja vožatych oktjabrjatskich grupp. Moskva 1961.

Pionýrské noviny 1958-1961, 1963.

Plamen. Časopis Dismanova rozhlasového dramatického souboru 1953/1954.

SVATOŠOVÁ, Jana: Jiskry a dvanáct měsićcki : Vedoucí hvězdičky jisker. Praha 1974.

SVATOŠOVÁ, Jana: Jiskry a dvanáct měsićkủ: Vedoucí oddílu jisker. Praha 1973.

V. sjezd Československého svazu mládeže. Praha 1967.

Vedoucí pionýrů 1957-1958, 1961-1965.

Věstník ministerstva školství a kultury 1960.

VIII. plenární zasedání Ústředního výboru ČSM 21.-22. prosince 1957. Praha 1957.

Vychovatel 1959.

Vychovávatel'1960/1961, 1961/1962.

\section{Internetové zdroje}

http://www.daildeca.cz/fischerjunvpred.html

https://bg.wikipedia.org/wiki/Чавдарски_чети_в_Народна_република_Българ

https://it.wikipedia.org/wiki/Oktjabrjata

https://ru.wikipedia.org/wiki (Октябрята)

\section{Literatura}

BOLZ, Alexander - LUND, Jörgpeter - POßNER, Wilfried: Die Pionierorganisation „Ernst Thälmann“ in der DDR. Berlin 2009.

ERDEI, Ildiko: „The Happy Child“ as an Icon of Socialist Transformation. Yuguslavia's Pioneer Organisation. In: LAMPE, John R. - MAZOWER, Mark (eds.): Ideologies and National Identities. New York 2004, s. $154-179$.

KELLY, Catriona: Children's World: Growing Up in Russia 1890-1991. New Haven - London 2007.

KNAPÍK, Jiří - FRANC, Martin a kol.: Mezi pionýrským šátkem a mopedem : Děti, mládež a socialismus v českých zemích 1948-1970. Praha 2018.

SEKERÁKOVÁ, Anna: Př́iběh Mateřidoušky. Diplomová práce, Filozofická fakulta Univerzity Karlovy. Praha 2009.

Какво се случи Преди '89-та? Исторически Сборник за Комунизма в България. Софиа, май 2017.

79 Dále též KNAPÍK, J. - FRANC, M. a kol.: Mezi pionýrským šátkem, s. 366.

80 SVATOŠOVÁ, Jana: Jiskry a dvanáct měsíčků : Vedoucí oddílu jisker. Praha 1973; TÁŽ: Jiskry a dvanáct měsíčků: Vedoucí hvězdičky jisker. Praha 1974. 


\section{Summary}

\section{Jiskry (Sparks) in the Pioneer Organisation of the Czechoslovak Youth Union (1959-1967)}

This study describes the establishment of Jiskry (Sparks) as a part of the Pioneer Organisation of the Czechoslovak Youth Union in 1959 which strengthened the system of extracurricular education for children too young for the Pioneer who until then had not been a part of the Czechoslovak Youth Union. The inclusion of systematic work with the youngest age group of schoolchildren in the Czechoslovak Youth Union can be assessed as rather problematic. It seems that at the turn of the 1950s and 1960s, at the time of Khrushchev's bold visions which inspired the political authorities in Czechoslovakia, Jiskry should have helped to further expand the membership of the Pioneer Organisation of the Czechoslovak Youth Union and present it as a truly mass children's organization. In addition, Jiskry were to strengthen the recruitment of the youngest pioneers at the age of nine since the basic political rationale for their existence was to prepare children to enter the Pioneer Organisation. However, this formal approach exacerbated the difficulties that the Pioneer was facing at that time. Although the sparks managed to create a robust background in the media (television broadcasts, columns in children's magazines) and a network of activities (games, summer camps) which complemented the existing network of extracurricular facilities for children aged six to nine, they could not provide adequate pedagogical background by adult group leaders in the long run, a serious problem faced also by the proper Pioneer clubs. In reality, working with the youngest children relied on the so-called little star leaders (vedoucí hvězdičky), most often female pupils in $7^{\text {th }}$ to $9^{\text {th }}$ grades, who, despite their effort, could not provide pedagogically valuable care and upbringing. These problems led authorities (together with the preparation of the reform of the Pioneer Organisation of the Czechoslovak Youth Union) to gradually dissolve Jiskry in 1967 by stopping the admission of 1st grade pupils and at the same time lowering the age limit for entering the Pioneer Organisation to eight years. 